\title{
Analysis of the Proton Exchange Membrane Fuel Cell in transient operation
}

\author{
Andrzej Wilk ${ }^{1, *}$, and Daniel Węcel ${ }^{1}$ \\ ${ }^{1}$ Silesian University of Technology (STU), Institute of Power Engineering and Turbomachinery, \\ 44-100 Gliwice, Konarskiego 18, Poland
}

\begin{abstract}
Currently, fuel cells are increasingly used in industrial installations, means of transport and household applications as a source of electricity and heat. The paper presents the results of experimental tests of PEMFC at variable load, which characterizes the cell's operation in real installations. The measurements made show changes in the performance of the fuel cell during step changing or smooth changing of an electric load. Load was carried out as a change in the current or a change in the resistance of the receiver. The analysis covered the times of reaching steady states and the efficiency of the fuel cell system taking into account additional devices. The analysis of the measurement results will allow determining the possibility of using fuel cells in installations with a rapidly changing load profile and indicate possible solutions to improve the performance of the installation.
\end{abstract}

\section{Nomenclature}

$\mathrm{V}_{\mathrm{i}} \quad$ transient voltage $(\mathrm{V})$

I fuel cell current (A)

$\mathrm{V}_{\mathrm{s}} \quad$ steady-state voltage $(\mathrm{V})$

$\mathrm{T}_{0} \quad$ inlet coolant temperature $\left({ }^{\circ} \mathrm{C}\right)$

$\mathrm{T}_{1} \quad$ outlet coolant temperature $\left({ }^{\circ} \mathrm{C}\right)$

$\mathrm{T}_{2} \quad$ exhaust air temperature $\left({ }^{\circ} \mathrm{C}\right)$

$\mathrm{p}_{\mathrm{H} 2} \quad$ hydrogen inlet pressure (bar)

$\mathrm{p}_{\mathrm{H} 2 \mathrm{FC}} \quad$ hydrogen operating pressure (mbar)

$\mathrm{t}$ time $(\mathrm{s})$

$\tau_{\mathrm{V}} \quad$ voltage response time (s)

$\mathrm{P} \quad$ power $(\mathrm{W})$

$\Delta \mathrm{V}_{\max } \quad$ maximum voltage deviation $(\mathrm{V})$

$\lambda \quad$ excess air ratio (-)

\section{Introduction}

Fuel cells are one of the technologies considered for the production of electricity and heat, which is supposed to allow for optimal use of fuels. These are devices in which there is a direct conversion of chemical energy of fuel into electricity, in electrochemical processes, without thermal and mechanical transformations. Therefore, they are not subject to restrictions of the Carnot cycle, thanks to which it is possible to achieve efficiency even above $60 \%$ at low temperatures [1]. Hydrogen fuel cells have undergone intensive development in recent years, from experimental solutions to fully commercial equipment. The possibility of choosing different types of cells, with powers ranging from a few watts to even megawatts, allows using them in power supply systems of different kinds [2, 3]. They can operate in individual power supply systems and can be connected to the power grid [4, 5]. Hydrogen fuel cells do not have to work continuously and react quickly to load changes [6]. Unfortunately, a change in their parameters is observed during the work $[7,8]$. This is due to the relatively rapid degradation of the fuel cell components and their sensitivity to temperature.

Considering the possibility of using Proton Exchange Membrane Fuel Cell (PEMFC) as the only power source in autonomous instances, one should consider their dynamic properties [9]. The tests carried out indicate rapid changes in the PEMFC voltage, exceeding the set state values, with abrupt changes in the current [10]. The nature of changes in fuel cell voltage depends on the parameters, i. e. pressure or temperature, but first of all on the change in load power and load current $[11,12]$.

\section{Test facility}

The applied power supply systems using fuel cells are built in the form of stacks consisting of several dozen to even several hundred individual fuel cells connected in series. Characteristics of fuel cells constructed in such a way do not depend significantly on the number of connected cells, i. e. on the power of the whole stack. They depend on the characteristics of a single cell. Low-power, water-cooled fuel cell was used in the research. Water cooling is typically used in higher power units where more efficient heat dissipation is required and at the same time it is easier to use the heat for heating purposes. Such solutions are used both in stationary and mobile systems (e. g. in transport). The results of the research will therefore be able to relate to fuel cells of higher power.

The fuel cell stack tested consists of 42 PEM cells connected in series, manufactured by Schunk Bahn- und

*Corresponding author: andrzej.t.wilk@polsl.pl 
Table 1. Test fuel cell parameters

\begin{tabular}{lc}
\hline \multicolumn{1}{c}{ Parametr } & Range \\
\hline Operating voltage $(\mathrm{V})$ & $20-45$ \\
Current $(\mathrm{A})$ & $\max 18$ \\
Nominal power $(\mathrm{W})$ & 360 \\
Excess air ratio & $1.5-4.0$ \\
Permitted inlet pressure range $(\mathrm{bar})$ & $1.0-17.0$ \\
Hydrogen operating pressure $(\mathrm{mbar})$ & $50-360$ \\
Hydrogen quality: Minimum/ & $4.0=99,99 \% /$ \\
Recommended & $5.0=99,999 \%$ \\
Operating temperature $\left({ }^{\circ} \mathrm{C}\right)$ & $42-55$ \\
Exhaust air temperature $\left({ }^{\circ} \mathrm{C}\right)$ & $10-60$ \\
Ambient temperature $\left({ }^{\circ} \mathrm{C}\right)$ & $10-30$ \\
Coolant temperature $\left({ }^{\circ} \mathrm{C}\right)$ & $10-57$ \\
Heating power $(\mathrm{W})$ & $\max 400$ \\
Maximum fuel consumption for rated & $0-4$ \\
output power $(\mathrm{dm} / \mathrm{min})$ & $\max 65$ \\
Coolant volume flow rate $\left(\mathrm{dm}{ }^{3} / \mathrm{h}\right)$ & $\max 240$ \\
Coolant pressure $(\mathrm{mbar})$ & $\max 320$ \\
Air volume flow rate $\left(\mathrm{dm}^{3} / \mathrm{min}\right)$ & $\max$ \\
Air pressure $(\mathrm{mbar})$ &
\end{tabular}

Industrietechnik GmbH, type FC-42/HLC [13]. Its basic parameters are presented in Table 1.

The parameters achieved by the actual fuel cell may differ by up to $15 \%$ from the values stated by the manufacturer. This is due to the varying degrees of humidification of the membrane, its temperature and the excess air ratio. The hydrogen consumption (with the required minimum purity of $99.99 \%$ ) is $4 \mathrm{dm}^{3} / \mathrm{min}$ at rated load. To ensure continuity of substrate supply to the fuel cell, hydrogen is supplied with small overpressure (required to overcome flow losses). The air flow is forced by a compressor.

The fuel cell stack is connected to a control system equipped with: a compressor (allowing to feed the regulated quantity of air to the cell, to ensure first of all a constant value of the excess air ratio), a hydrogen reducer (reducing the pressure of hydrogen taken from pressure vessels), a water cooling system (limiting the maximum working temperature of the cell), control and protection systems [14]. The system enables regulation of: excess air ratio $\lambda$ within $1.5 \div 4.0$ every 0.1 , cooling water temperature $\mathrm{T}_{1}$ within $42 \div 56^{\circ} \mathrm{C}$ every 1 degree. Fig. 1 shows a diagram of the analysed PEM fuel cell system with auxiliary devices.

Fuel cell control systems are generally programmed in such a way as to prevent damage to the fuel cell and at the same time ensure the continuous operation of the system. For the fuel cell under analysis, the limits are: maximum current $(18 \mathrm{~A})$, minimum voltage $(20 \mathrm{~V}$, corresponding to approximately half of the non-load state) and maximum cooling water temperature $\left(57^{\circ} \mathrm{C}\right)$.

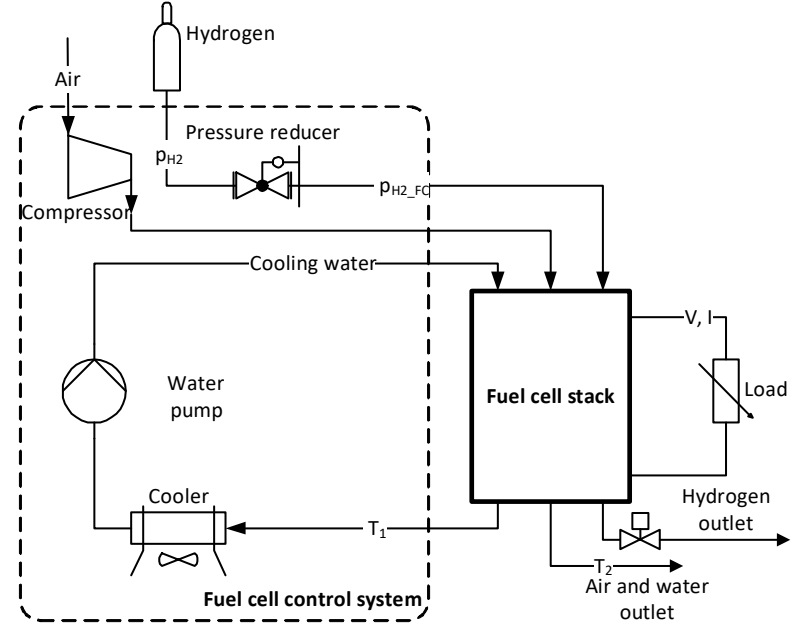

Fig. 1. Diagram of the fuel cell stack measurement system

If these values are exceeded, the load is disconnected within a short period of time. As a result, the working area is very limited in relation to the theoretical characteristics. The full characteristics of the FC-42/HLC fuel cell together with the working area are shown in Fig. 2. It is possible to increase the current of the fuel cell up to $25 \mathrm{~A}$ and to reduce the voltage up to $15 \mathrm{~V}$ only for a short time (about 1 second).

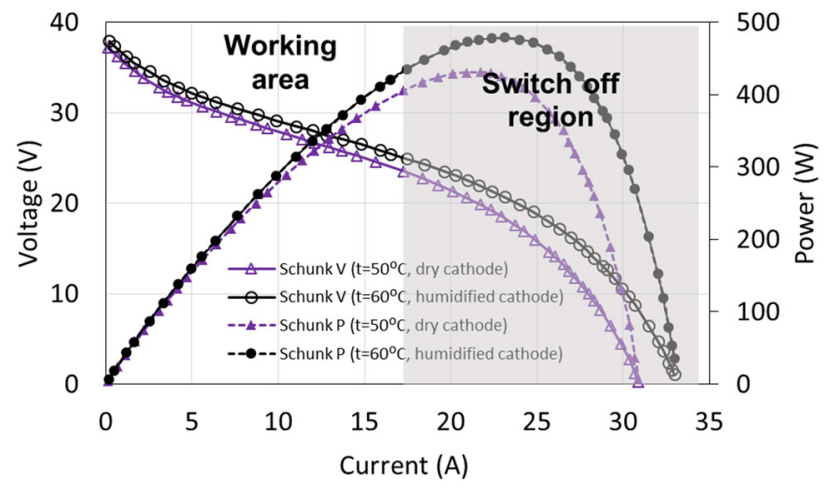

Fig. 2. Fuel cell characteristics and operating area

In order to improve the working conditions of the fuel cell, the control system opens the hydrogen outlet valve at certain intervals (depending on the load current), which results in the so-called purging of the fuel cell from the anode side. This allows the removal of excess moisture and the regeneration of the membrane, but at the same time the hydrogen flow is temporarily increased and the inlet pressure of $\mathrm{p}_{\mathrm{H} 2} \mathrm{FC}$ is reduced. The heat exchange in the cooling system is intensified by cyclically activated fans. This results in fluctuations in the operating temperature of the fuel cell. Therefore, it is difficult to maintain stable working conditions of a fuel cell. For this reason, the static characteristics obtained are approximate.

All auxiliary devices, i. e. compressor, cooling water pump, cooler fans, valves, measuring system were supplied from a separate source. The power consumed by these units varied according to the load and temperature of the cooling water [15]. 


\section{Static characteristics of the fuel cell}

The main operating characteristics allow determining the parameters of fuel cell operation for different loads and operating conditions. Examples of characteristics, determined for two temperatures and compared with the manufacturer's data, are shown in Fig. 3.

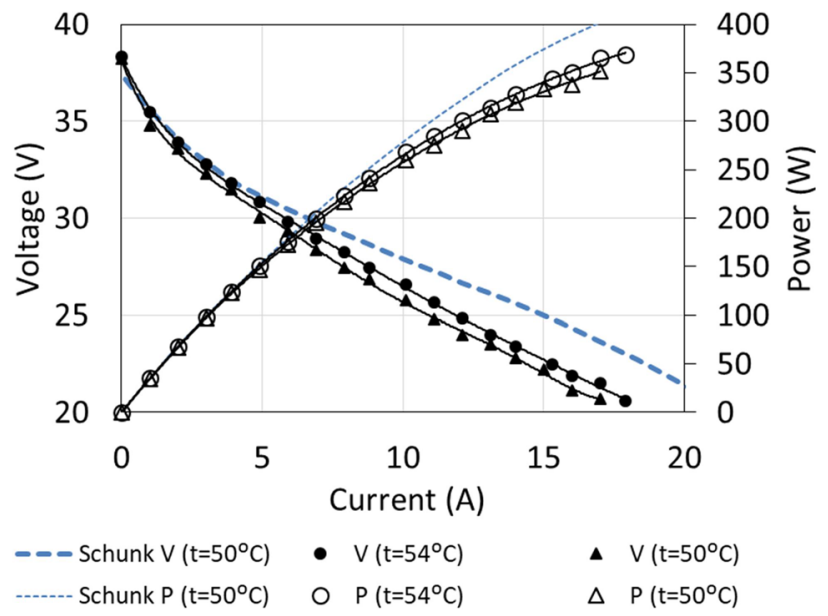

Fig. 3. Fuel cell characteristics obtained by means of measurements

Although the measurements were carried out on almost new cells (the total service life was several hours), the characteristics differed from those given by the manufacturer. The biggest differences can be observed in the maximum load area, where they exceed even $10 \%$. This is characteristic for fuel cells with a significant degree of degradation $[7,8]$.

Tests of the fuel cell in steady states enabled the determination of current and voltage characteristics for different operating temperatures $T_{1}$ (in the range $42 \div$ $54^{\circ} \mathrm{C}$ ) and with different excess air ratio (in the range $\lambda=1.5 \div 4)$.

The influence of both temperature $T_{1}$ and $\lambda$ ratio on the characteristics of the cell was observed. The voltage, and thus the power of the fuel cell, increased by about $5 \%$ with the increase of the excess air ratio $\lambda$ from the minimum to the maximum value (for the electric current of $14 \mathrm{~A}$ ), as shown in Fig. 4.

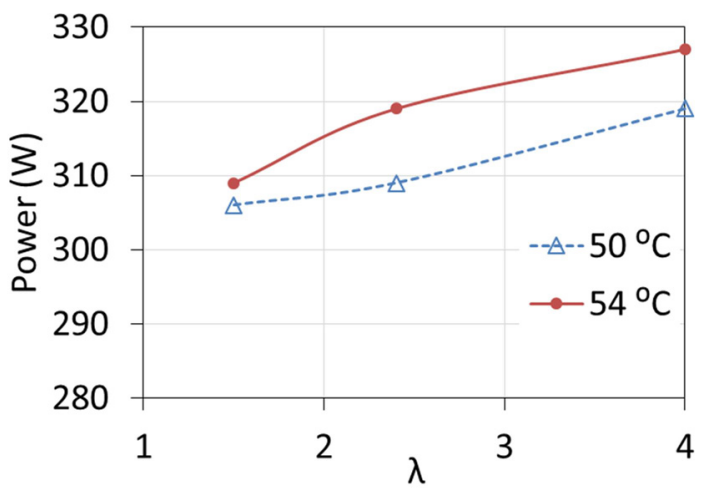

Fig. 4. Changes in fuel cell power at different inlet coolant temperature $T_{1}$ and different excess air ratio $\lambda$
At the same load (close to the rated load), the temperature increase by $1{ }^{\circ} \mathrm{C}$ caused the voltage increase by about $0.7 \%$. At low loads, the influence of temperature and $\lambda$ ratio is much smaller.

The characteristics may also depends by the operation of a compressor supplying air which, at low electric currents and small values of the set excess air factor $\lambda$, worked at minimum rotational speed without providing the set value of $\lambda$. In steady states, the flow rate of hydrogen consumed was always directly proportional to the electric current.

\section{Transient tests}

When analysing the operation of fuel cells, several states may be taken into account: start-up, no load, increase of load, operation under constant load, reduction of load, shutdown. The article focuses only on the work of the cell itself, does not analyze the preparation for work and the transient states of auxiliary equipment. It is assumed that all these devices are ready for operation. During the startup of PEMFC it is necessary to remove air from the anode pipes. This can be achieved with inert gas (e. g. nitrogen) and then hydrogen must be supplied to activate the anode. The moist air supply from the cathode side allows the membrane to be pre-humidified. These actions always take place without a load and are intended to achieve at least the rated voltage (for the tested cell $24 \mathrm{~V}$ ). The start-up process can take from a few to several dozen seconds, depending on the size of the installation and the time that has elapsed since the last start-up, and can be completed when the voltage reaches a value close to non-load state. For the fuel cell under analysis, the minimum starting time from cold start to rated output is about 2 minutes.

In the non-load state, the fuel cell is prepared to connect the load. On the anode side there is hydrogen with appropriate parameters and air is supplied to the cathode side. The membrane is moistened to allow proton conduction. The no-load condition is always present when the load is disconnected. The no-load voltage may vary depending on: the degree of humidification of the membrane, the temperature and the degree of degradation of the fuel cell. In this state, it is necessary to power the auxiliary equipment from a separate source. In fuel cells of high power it is necessary to use compressors allowing for air supply to the cathode channels.

At a constant pressure of hydrogen supply from the pressure reservoir ( 2 bar), the reduction valve keeps the operating pressure $\mathrm{p}_{\mathrm{H} 2} \mathrm{FC}_{\mathrm{F}}$ of the hydrogen at the inlet to the anode between 300 and 310 mbar. It depends on the current of the fuel cell. Lower pressure is achieved at maximum load. At the moment of anode purging the operating pressure drops can be observed to $280 \mathrm{mbar}$, but they do not have a significant influence on the voltage and current of the fuel cell. In all tests, the value of the excess air ratio was set to $\lambda=4$.

Fuel cells are DC power sources therefore they are connected to resistive receivers. All tests were carried out with the use of electronic load, which allowed for a rapid change of resistance. This way of loading the fuel cell is closer to the real operating conditions. The main 
parameters analysed in the tests were: voltage and current of the cell, which determine the obtained power.

\section{Indicators of changes in fuel cell parameters}

In order to describe the transition states in the fuel cell, several indicators have been defined [16].

Voltage fluctuation rate $\varepsilon_{\mathrm{V}}$ - dimensionless value indicating the difference between the temporary value of voltage and the voltage in the steady state.

$$
\varepsilon_{V}=\frac{\left|V_{i}-V_{s}\right|}{V_{s}}
$$

Maximum voltage deviation from the steady value $\Delta \mathrm{V}_{\max }$ - a value indicating the maximum difference between the temporary value of voltage after load change and the voltage in the steady state.

$$
\Delta V_{\max }=\left|V_{i(\min / \max )}-V_{s}\right|
$$

Voltage response time $\tau_{V}$ - time from load change to voltage fluctuation rate below $2 \%$.

$$
\tau_{V}=t\left(\varepsilon_{V} \leq 2 \%\right)
$$

\section{Results and discussion}

\subsection{Changing the load on the fuel cell}

The fuel cell was started (after two weeks of downtime) and loaded to moisten the membrane and stabilize the operating conditions. It took about 20 minutes to prepare the fuel cell for research. The tests began with the connection of a receiver with a constant resistance. Fig. 5 shows changes in fuel cell parameters when the electrical circuit is connected with a resistance of $3 \Omega$. It corresponds to a load of approx. $60 \%$ of the rated value. The circuit was opened after $600 \mathrm{~s}$ and reloaded with the same resistance after next $120 \mathrm{~s}$.

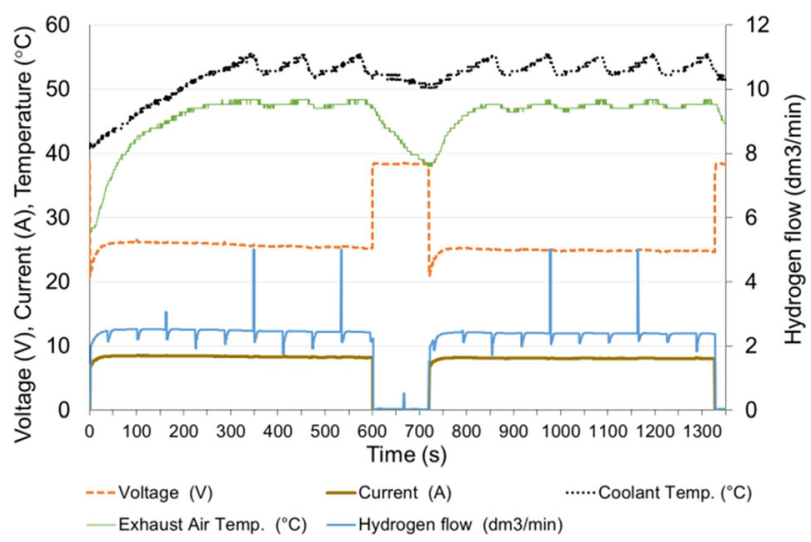

Fig. 5. Fuel cell parameters changes at rapid increase of load

Before the load, the cell operated for about 15 minutes with the resistance of the receiver $1.5 \Omega$, therefore, before the first series of measurements, the cell was heated and the cooling water had the temperature at the inlet $\mathrm{T}_{0}=32^{\circ} \mathrm{C}$.

At the moment of a rapid load (in less than 0.1 second), the current increases to approx. $80 \%$ of the steady state and within 30 seconds reaches $98 \%$ of the steady state. The voltage drops rapidly below the steady state value and then rises to $98 \%$ of the steady state value after 30 seconds. It is assumed that the steady state is reached when the exhaust air temperature $T_{2}$ is stable. The time to reach steady state depends on the initial temperature of the fuel cell. The parameters of fuel cell are stable except voltage - it can be observed slow decreasing of voltage within 20 minutes after the load is switched on.

In addition to electricity generation, the fuel cell is also a source of heat. The amount of heat produced is dependent on the current. In the case of water-cooled fuel cells, most of the heat is transferred to the cooling system. Only a few percent of the generated heat is discharged together with the exhaust air and via the housing into the environment [15]. The cooling water flow is constant, so by increasing load of the fuel cell increases the operating temperature. Due to temperature restrictions, the temperature of the cooling water does not exceed $57^{\circ} \mathrm{C}$. This is due to the periodical operation of the radiator fans. The starting moment of the fans is clearly visible in Fig. 5, when the temperature of the cooling medium starts to drop rapidly with the unchanged load. This method of cooling stabilizes the temperature and its fluctuations are $2-5^{\circ} \mathrm{C}$.

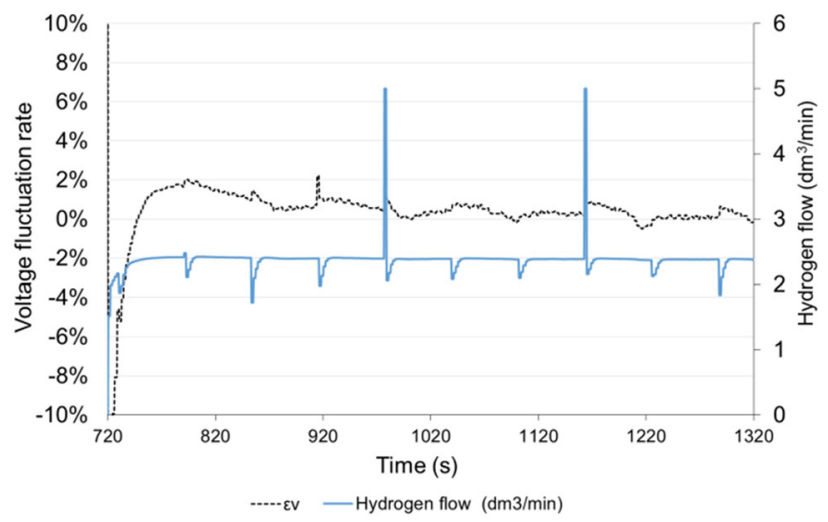

Fig. 6. Voltage fluctuation rate $\varepsilon_{\mathrm{V}}$ and hydrogen flow with time under step resistance change

The hydrogen flow is proportional to the current. The visible momentary fluctuation of the stream is due to the purging of the anode. With a constant current of the fuel cell, the purge valve opens at equal intervals. The hydrogen flow temporarily increases to its maximum value and then decreases due to the necessity to increase the operating pressure in the anode area. Purging the anode causes a slight increase in the voltage of the cell by about $0.5 \%$. The voltage returns to the previous value after approx. $10 \mathrm{~s}$. The time characteristics shown in Fig. 6 were obtained, when the load was switched on again, therefore the time scale starts from $720 \mathrm{~s}$. In the long period, anode purging has a positive effect on the stabilization of the fuel cell operating conditions. 


\subsection{Step increase and decrease of fuel cell load}

Subsequent tests were carried out by increasing and then decreasing in steps the resistance of the receiver. Such a method of load of the power source corresponds in practice to connecting successive receivers [17]. The operating time at subsequent loads was 5 minutes.

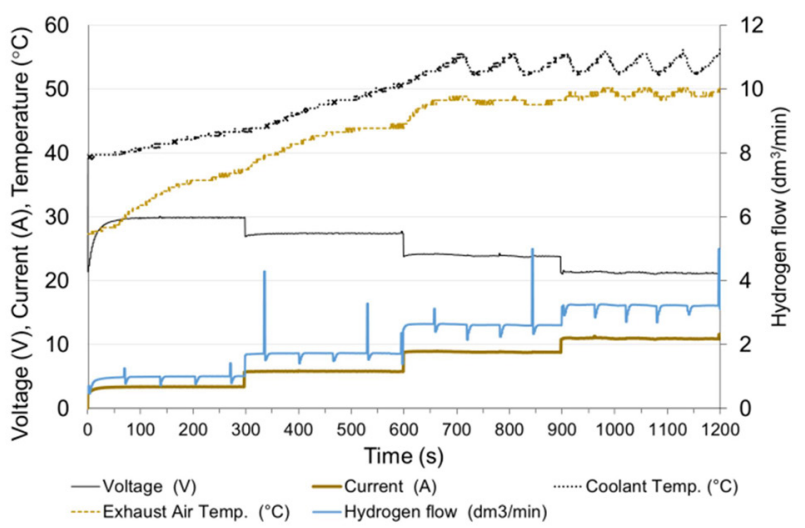

Fig. 7. Changes in fuel cell parameters during step increasing of the load

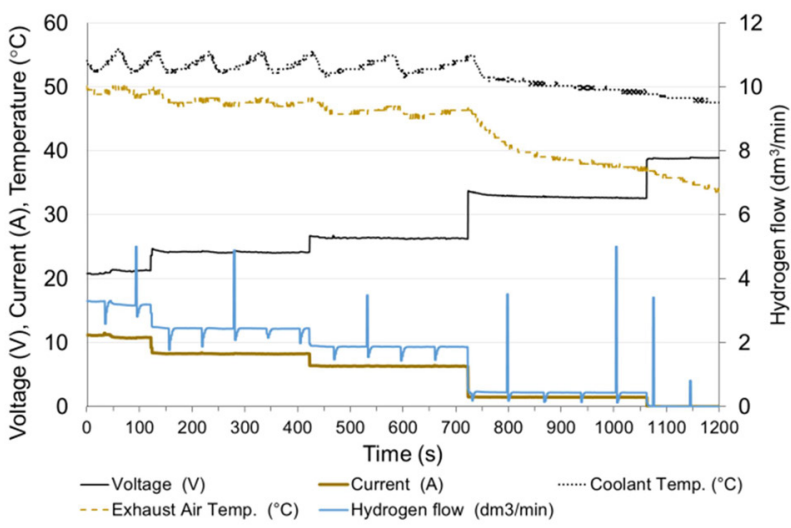

Fig. 8. Changes in fuel cell parameters during step decreasing of the load

In Fig. 7 and Fig. 8 it can be seen that the greatest deviation of voltage from the stable value occurs at the transition from non-load to low load and when the load is reduced to small values. With these changes, the time of setting the voltage $\tau_{V}$ to the level of $98 \%$ of the set value is approx. 50 seconds. Load changes while the cell is in operation do not cause significant voltage changes. The fixed value is reached in less than $1 \mathrm{~s}$. When the load increases (the resistance of the receiver decreases), the voltage drops rapidly below the set value and then increases (this is particularly visible for low load - Fig. 9). When increasing the load, the voltage on the fuel cell increases rapidly above the set value, and then decreases to the voltage of the set state (Fig. 10). The lines on Fig. 9 and Fig. 10 show voltage changes obtained at a step change of the load described by the value of the current in steady states. In all analyzed cases the resistance of the receiver was changed, so that the nature of the changes in the current is the same as the voltage.

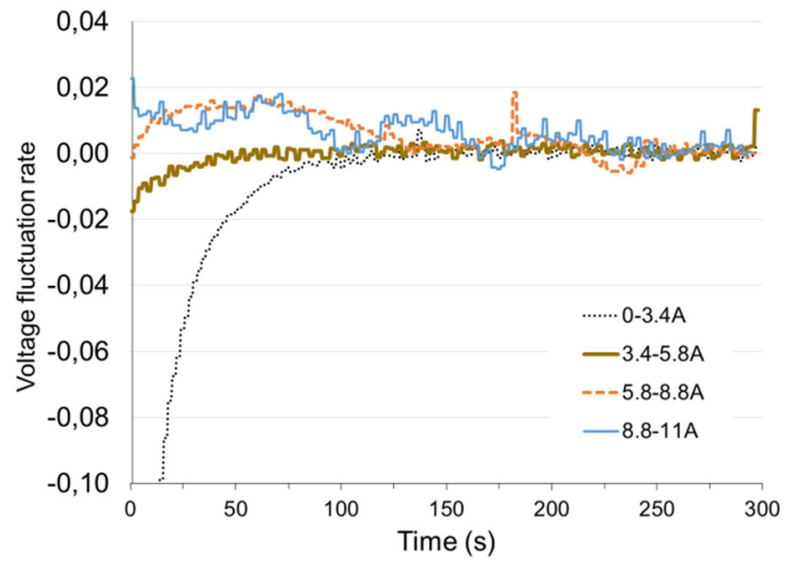

Fig. 9.Voltage fluctuation rate $\varepsilon_{\mathrm{V}}$ with time under load increase

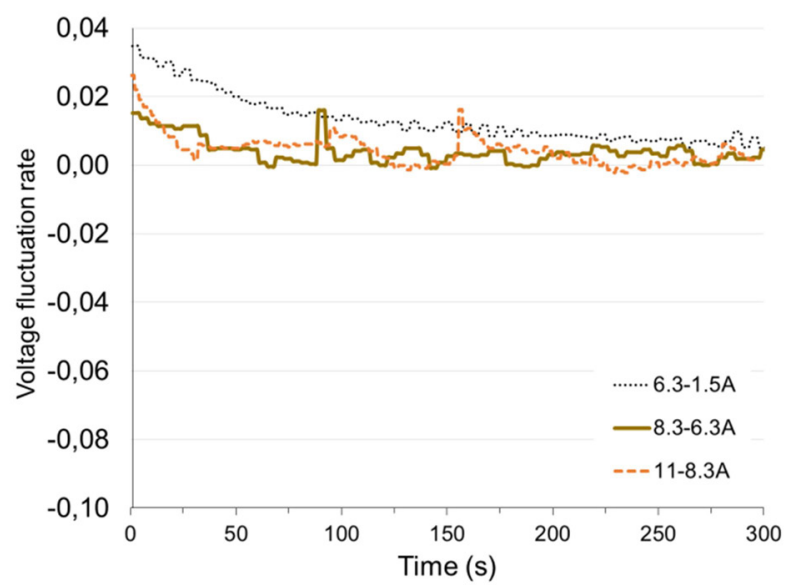

Fig. 10.Voltage fluctuation rate $\varepsilon_{\mathrm{V}}$ with time under load decrease

In the case of DC sources, the power generated is a square function of the current. The power generated by the fuel cell thus changes in the same way as the current, and only the fluctuations are more significant.

At high loads, although the voltage very quickly reaches the set state, the fluctuations resulting from anode purging and higher temperature fluctuations are visible clearly. This is due to the fact that at higher loads the heat flow generated in the fuel cell increases, which results in an increase of the frequency of switching on the fans in the cooling system.

\section{Conclusions}

The main purpose of the research was to check how the parameters of a fuel cell change when the resistance of the receiver changes and whether it is possible to provide adequate power of fuel cell to power the receivers in a short time.

Test shows, that PEMFC reacts very quickly to changes in load, but moves relatively slowly to a steady state at a steep increase in load from non-load state. When only a load change occurs, the duration of the voltage response time $\tau_{\mathrm{V}}$ of the fuel cell is several seconds. At low currents this time can be extended up to 50 seconds. Small voltage changes can be observed even up to 300 seconds 
after a jumping load change occurs. This is related to the determination of the temperature of the fuel cell and the anode purging process.

During a load change, the PEMFC operating point did not move along the steady state line, which can cause the limit values to be exceeded under adverse conditions and when the load increases too much. This applies mainly to the limitation of the minimum voltage value. The consequence of this may be the switching off the fuel cell, even though the fuel cell in the steady state should work at a given load.

Taking into account the amount of electricity produced and the amount of hydrogen consumed during the tests, the efficiency of the fuel cell tested is approximately $43 \%$. This value can be considered to be relatively high, especially when considering the operation of a cell with frequent changes of load. The calculation of efficiency does not take into account the energy of internal loads.

Publication supported as a part of the Rector's grant in the area of scientific research and development works, Silesian University of Technology, Poland, grant number RGJ 08/050/RGJ18/0152.

\section{References}

1. J. Larminie, A. Dicks, Fuel Cell Systems Explained, $2^{\text {nd }}$ edition, John Wiley \& Sons Ltd, England, (2003), ISBN 0-470-84857-X

2. L. Barelli, G. Bidini, F. Gallorini, A. Ottaviano, Dynamic analysis of PEMFC-based CHP systems for domestic application, Applied Energy, 91, pp. 13-28, (2012)

3. The Fuel Cell Industry Review 2018, December 2018, E4tech

4. Y. Wang, K. Chen, J. Mishler, A review of polymer electrolyte membrane fuel cells: Technology, applications, and needs on fundamental research. Applied Energy, 88, pp. 981-1007 (2011)

5. J. Kotowicz, D. Węcel, M. Jurczyk, 2018, Analysis of component operation in power-to-gas-to-power installations, Applied Energy, 216, pp. 45-59, (2018)

6. Y. Tang, W. Yuan, M. Pan, Experimental investigation on the dynamic performance of a hybrid PEM fuel cell/battery system for lightweight electric vehicle application, Applied Energy, 88, pp. 68-76, (2011)

7. A. Aquino, J. Heng, Current and Temperature Distributions in a PEM Fuel Cell, A Major Qualifying Project Report Submitted to the faculty of Worcester Polytechnic Institute (2017)

8. A. Verhage, J. Coolegem, M. Mulder, M. Yildirim, F. de Bruijn, 30,000 h operation of a $70 \mathrm{~kW}$ stationary PEM fuel cell system using hydrogen from a chlorine factory, International Journal of Hydrogen Energy, 38, pp. 4714-4724, (2013)

9. J. Cieśliński, T. Kaczmarczyk, B. Dawidowicz, Dynamic characteristics of the proton exchange membrane fuel cell module, Archives of Thermodynamics, vol. 39, No. 4, pp. 125-140, (2018)
10. J. Hamelin, K. Agbossou, A, Laperriere, Dynamic behavior of a PEM fuel cell stack for stationary applications, International Journal of Hydrogen Energy, 26, pp. 625-629, (2001)

11. H. Sun, G. Zhang, L. Guo, A Study of dynamic characteristics of PEM fuel cells by measuring local currents, International Journal of Hydrogen Energy, 34 (13), pp. 5529-5536, (2009)

12. J. Cho, H. Kim, K. Min, Transient response of a unit proton-exchange membrane fuel cell under various operating conditions, Journal of Power Sources, 185 (1), pp. 118-128, (2008)

13. Handbuch für Schunk Brennstoffzellen-Stacks FC42/HLC. Schunk Bahn- und Industrietechnik GmbH, Wettenberg, Rev 3.0 [ger] (06/2010)

14. FC-42 Evaluation Kit, Instruction Manual, Version 1.1, April 2009, Heliocentris Energiesysteme GmbH, Berlin, Germany.

15. W. Ogulewicz, D. Węcel, G. Wiciak, H. Łukowicz, J. Kotowicz, T. Chmielniak, Pozyskiwanie energii z ogniw paliwowych typu PEM chłodzonych ciecza, Monografia, Wydawnictwo Politechniki Śląskiej, Gliwice, Poland, (2010)

16. J. Zhao, Q. Jian, L. Luo, B. Huang, S. Cao, Z. Huang, Dynamic behavior study on voltage and temperature of proton exchange membrane fuel cells, Applied Thermal Engineering, 145, pp. 343351, (2008)

17. J. Benziger, E. Chia, J. Moxley, I. Kevrekidis, The dynamic response of PEM fuel cells to changes in load, Chemical Engineering Science, 60, pp. 17431759, (2005) 